\title{
Habitat-specific benthic metabolism in a Mediterranean-type intermittent stream
}

\author{
Katarzyna Sroczyńska ${ }^{1 *}$, Marilia Claro $^{2}$, Pedro Range ${ }^{3}$, Katarzyna Wasiak $^{4}$, \\ Adrianna Wojtal-Frankiewicz ${ }^{5}$, Radhouan Ben-Hamadou ${ }^{3}$, Francisco Leitão ${ }^{2}$ and Luís Chícharo ${ }^{1,6}$ \\ 1 Faculty of Science and Technology, Campus of Gambelas, University of Algarve, 8005-139, Faro, Portugal \\ 2 Centro de Ciências do Mar, Campus of Gambelas, University of Algarve, 8005-139, Faro, Portugal \\ 3 Department of Biological and Environmental Sciences, College of Arts and Sciences, Qatar University, Doha, Qatar \\ 4 Bieszczadzki Park Narodowy, ul Belzka 7, Ustrzyki Dolne 38-700, Poland \\ 5 Department of Applied Ecology, University of Lodz, Banacha 12/16 Str., 90-237 Lodz, Poland \\ ${ }^{6}$ Centro de Investigação Marinha e Ambiental (CIMA) Universidade do Algarve, Campus de Gambelas, 8005-139 Faro, Portugal
}

Received 23 October 2015; Accepted 9 March 2016

\begin{abstract}
A modified flow-through chamber method was used to measure gross primary production (GPP), net primary production (NPP), community respiration (CR) and associated environmental variables in an intermittent Mediterranean-type stream in Southern Portugal. Three common types of in stream habitats were targeted: cobble $(\mathrm{C})$, cobble covered with filamentous algae $(\mathrm{C}+\mathrm{A})$ and leaf litter (LL). NPP, GPP and CR differed significantly among all three habitats. GPP increased with chlorophyll $a$ and, less strongly, with photosynthetic active radiation and, therefore, was highest in $\mathrm{C}+\mathrm{A}$ habitat. The highest $\mathrm{CR}$ was in LL and its variation was best determined by ash-free dry mass (AFDM) of plant litter. Higher respiration in LL was related to heterotrophic activity and, to a lesser extent, to autotrophic respiration associated with periphyton. We observed a decrease of production efficiency of primary producers with AFDM in C + A and C habitats. Our results demonstrate that each habitat type should be considered as a discrete metabolic entity and that particular sets of environmental factors are responsible for habitat specific metabolic responses. Scaling up measurements from discrete habitat patches to the entire reach or stream should not be done by extrapolating the results of a single habitat type and will require quantification of habitat coverage, at the appropriate scale.
\end{abstract}

Key words: benthic metabolism / Quarteira River Basin / light and dark incubations / benthic habitats

\section{Introduction}

Streams are heterogeneous environments, with fluctuating channel structure shaped by geological and hydrological processes across broad spatial and temporal scales (Poff and Ward, 1989; Elosegi et al., 2010). These dynamics produce patchy distributions of autotrophic and heterotrophic organisms, influencing resource use and metabolic processes (Southwood, 1977; Pringle et al., 1988; Warnaars et al., 2007). A rich body of literature has been built around the influence of habitat characteristics and habitat heterogeneity on organization of community structure (Rabeni and Minshall, 1977; Townsend and Hildrew, 1994; Palmer and Poff, 1997; Wallace et al., 1997; Beisel et al., 1998, 2000; Armitage and Cannan, 2000; Brown, 2003). We know that habitat heterogeneity contributes directly and indirectly to biodiversity and

\footnotetext{
*Corresponding author: kasiasroczynska@gmail.com
}

ecosystem functions such as primary production, decomposition and nutrient cycling (Wallace et al., 1997; Lepori et al., 2005; Gessner et al., 2010). However, relatively few studies directly investigated how habitat patchiness modulates ecosystem-level processes (Pringle et al., 1988; Gustafson, 1998). This is of increasing concern, as the rising global threat of habitat loss and fragmentation impels us to better understanding how habitat-specific dynamics influence overall ecosystem processes. Benthic community metabolism is a conspicuous biological process and it integrates how whole communities are influenced by environmental variables across spatial and temporal scales (Fellows et al., 2006).

Few studies dedicated to benthic metabolism have demonstrated important differences in gross primary production (GPP), net primary production (NPP) and community respiration (CR), among different stream habitats (Rier and King, 1996; Clapcott and Barmuta, 2010). González Pinzón et al. (2014) demonstrated large 
spatial variation in metabolism within a stream, related to presence of different geomorphic units, bed materials and type of transient storage. Additionally, Fellows et al. (2006) demonstrated that separating experimental sites according to habitat type, improved the ability to explain variation in GPP and CR along an agricultural land-use disturbance gradient. Considerable differences in GPP and $\mathrm{CR}$ have also been reported along gradients of biofilm structural complexity (Sabater and Romaní, 1996) and community composition (Busch and Fisher, 1981; Velasco et al., 2003). These studies suggest that factors driving ecosystem metabolism are habitat-specific and different habitats act as separate metabolic components. Considering the functional role of individual habitats separately is, therefore, paramount to understanding how spatial heterogeneity and habitat patchiness influence ecosystem processes. This will greatly enhance our ability to predict how shifts relative habitat proportions can affect scaling estimates of stream metabolism.

The natural complexity of streams presents many challenges in measuring metabolism and numerous approaches have been developed to address these (Odum, 1956; Marzolf et al., 1994; Bott et al., 1997). By far, chamber-based measurements offer the most straightforward way to investigate the influence of separate river units on the metabolism (Fuss and Smock, 1996; Rier and King, 1996; Whitledge and Rabeni, 2000; Fellows et al., 2006; Clapcott and Barmuta, 2010). One of the main advantages of metabolic chambers is the capacity to separate specific habitats and isolate factors affecting metabolism within those habitats (Bott et al., 1978).

However, metabolic chambers can alter environmental conditions in ways that influence ecosystem metabolism (Dodds, 1991; Bott et al., 1997). For example, metabolic chambers have been shown to induce nutrient limitations and alter temperature, dissolved oxygen and water velocity conditions during the incubation. It is therefore important to improve the design of metabolic chambers, in order to obtain reliable data and facilitate direct comparison between studies.

Most chamber-based measurements focus on a single substrate unit, usually cobbles or gravel. This approach often fails to account for spatial changes in habitat structure, which can result in localized autotrophy in some habitats and heterotrophy in others (Whitledge and Rabeni, 2000). This oversimplification can lead to erroneous conclusions when extrapolating results from the habitat to the reach scale, especially in streams subjected to frequent changes in habitat structure, such as Mediterranean-type intermittent streams.

To this end, we quantified ecosystem metabolism rates (GPP, NPP, CR), in the three most common substrates in Mediterranean streams: cobbles (C), cobbles covered with filamentous algae $(\mathrm{C}+\mathrm{A})$ and leaf litter (LL). We used closed metabolic chambers modified from Wasiak (2009) where we applied an improved flow-through approach to overcome common problems associated with closed chamber techniques. In addition, we quantified water temperature, photosythetically active radiation - PAR, chlorophyll $a$, ash-free dry mass - AFDM, volume rate of water flow passing through the chamber - VR and nutrients (nitrite, phosphate and ammonium), allowing us to assess which factors contributed most to variation in stream metabolism among habitats. We predicted that habitats rich in biofilm and algae $(\mathrm{C}$ and $\mathrm{C}+\mathrm{A})$ would be net autotrophic, while the metabolism of LL would be strongly heterotrophic.

\section{Methods}

\section{Study site}

We conducted our study in the Algibre, a first-order intermittent stream in the Quarteira River Basin, Southern Portugal $\left(37^{\circ} 11^{\prime} 20^{\prime \prime} \mathrm{N}, 8^{\circ} 5^{\prime} 33^{\prime \prime} \mathrm{W}\right)$. The catchment area is $\sim 324 \mathrm{~km}^{2}$ with an elevation range from 14 to $515 \mathrm{~m}$. The average monthly temperature varies from 8 to $29^{\circ} \mathrm{C}$ and average annual rainfall is $625 \mathrm{~mm}$. Catchment land use consists of arable land with shrub and herbaceous vegetation with occasional olive tree and citrus plantations. Catchment geology is predominantly limestone and noncalcareous clay (Trindade et al., 2013). The studied reach was $400 \mathrm{~m}$ long and, on average, $8 \mathrm{~m}$ wide, with natural morphodynamics, uniform channel morphology and steady flow conditions. The average depth ranged from 20 to $50 \mathrm{~cm}$ in riffles and 50 to $100 \mathrm{~cm}$ in pools. At steady flow conditions (March-May) average discharge was $1.3 \mathrm{~m}^{3} . \mathrm{s}^{-1}$ and it gradually decreased towards warmer months, being as low as $0.026 \mathrm{~m}^{3} \cdot \mathrm{s}^{-1}$ (July-August) just before the channel completely dries. Channel substrate was predominantly gravel and cobble that during the summer season was densely covered by filamentous algae, chiefly Cladophora agg. and Vaucheria sp(p.). Riparian vegetation was dominated by Arundo donax, herbaceous vegetation and carob and olive trees. It was moderately developed, with a mean width of $3 \mathrm{~m}$ and occasional spots of very sparse canopy cover.

Annual variability in stream discharge directly affects substrate characteristics, the development of algae and macrophytes and accumulation of organic debris (Gasith and Resh, 1999). Along the margins, depositional pool zones were filled with accumulated LL from adjacent riparian vegetation, underlain with clay. We focused on the three most common in stream habitats: cobble (C), cobble covered with filamentous algae $(\mathrm{C}+\mathrm{A})$ and leaf litter (LL) (ESM-1, online material). These habitats represent distinct biological units that emerge through interactions between hydrological and geomorphological processes. Water velocity in the study reach was, on average, $0.09 \mathrm{~m} . \mathrm{s}^{-1}$, ranging from an average of $0.016 \mathrm{~m} . \mathrm{s}^{-1}$ in the LL deposition zones to $0.035 \mathrm{~m} . \mathrm{s}^{-1}$ in the cobble habitat and $0.178 \mathrm{~m} . \mathrm{s}^{-1}$ in cobble covered with algae.

\section{Experimental procedure}

Metabolic measurements were done in situ, from April 11 to June 27, 2014, a period characterized by stable 
flow conditions. Thirty-nine measurements of NPP, and CR were taken in haphazardly selected patches of each habitat type $(\mathrm{C}, 12 ; \mathrm{C}+\mathrm{A}, 15 ; \mathrm{LL}, 12)$ within the same $400 \mathrm{~m}$ reach. NPP and CR were measured using enclosed acrylic metabolic chambers modified from Wasiak (2009), with several improvements to study habitat-specific metabolism (ESM-1 and ESM-2, online materials).

We buried a metal chamber base $\sim 180 \mathrm{~mm}$ diameter in the stream sediments (two per habitat - randomly placed). A sample of intact substrate was removed from the river bottom and gently placed on the base, where it was left submerged in the stream for 3-5 days to allow macroinvertebrates recolonization (assuming that previous studies at perennial streams of O'Connor, 1991; Boyero, 2003; Oliveira et al., 2014 will be similarly applicable to our system). In most benthic community studies, the bases were left for longer periods (Bott et al., 1978). Unfortunately this was not possible in our study, due to the risk of theft or vandalism, which did occurred, with several bases disappearing during these periods of recolonization. Chamber bases with LL were prepared by filling the base unit with naturally fallen leaves of A. donax. Litter material was composed of senescent leaves, consisting of entire and partially degraded specimens ( $\approx 30-50 \%$ decomposed - personal observation) as well as remains of stems. During each $2 \mathrm{~h}$ incubation the base was sealed with an acrylic chamber (of $4.53 \mathrm{~L}$ volume), without disturbing the previously established community. The chambers were submerged to ensure they were free of air bubbles and to equilibrate the temperature in the chambers with the stream water (Bott et al., 1978). Each chamber was connected to a submersible pump by the inflow and outflow ports, so that the water flow inside the chamber was continuously homogenized, to allow stable dissolved oxygen readings. The inflow tube was deep seated inside the chamber in a manner to not resuspend the bottom sediment, but maximizing water homogenization. Submersible pumps were powered by a portable generator (ESM-2, online material).

NPP was measured as changes in dissolved oxygen inside each chamber, by using an oxygen sensor (YSI, Professional Plus), encased in an external flow cell (YSI, model 3059), which was sequentially connected to each of the chambers. When one measurement was finished, the flow cell was disconnected and connected to the next chamber. The tube connectors were always submerged during these operations, in order to avoid any air bubbles entering the line. This design allowed simultaneous incubation of several chambers, using only one oxygen probe. When incubations in light were finished, the water inside the chamber was completely exchanged. This was achieved by disconnecting the tubes from the circulation system and allowing the fresh water from the stream to enter the line. Considering that the flow rate of water passing through the chamber was, on average, $1.66 \times 10^{-5} \mathrm{~m}^{3} \cdot \mathrm{s}^{-1}$ the volume of the system was totally exchanged in $5 \mathrm{~min}$. Including this time interval we allowed approximately $20 \mathrm{~min}$ to half an hour time of acclimation before starting to measure community respiration. CR measures were done after covering the chamber with a black plastic wrapper to inhibit the light. Light and dark incubations lasted $2 \mathrm{~h}$ (DO concentration recorded at $12 \mathrm{~min}$ intervals). Incubations were initially paired with "blank" chambers, filled only with stream water (no substrate added to the bases), to assess the metabolism of the water column. $T$-tests $(P>0.05)$ showed that differences between corrected and uncorrected metabolic rates were negligible, so benthic metabolism rates were ultimately not corrected for water column metabolism. NPP and CR (mg DO m $\left.{ }^{-2} \cdot \mathrm{h}^{-1}\right)$ were calculated as follows:

$$
(\mathrm{NPP}, \mathrm{CR})=\left(\Delta \mathrm{O}_{2}\right) \times V \times\left(S^{-1}\right)
$$

where $\Delta \mathrm{O}_{2}$ is the change of oxygen concentration between beginning and end of the experiment per unit volume and time (mg DO L $\left.{ }^{-1} \cdot \mathrm{h}^{-1}\right), V$ the remaining volume (l) of the chamber (subtracted by the volume of substrate), $S$ the stone surface area $\left(\mathrm{m}^{2}\right)$ and in case of chamber with LL is the area occupied by LL, which was approximately the area of the base.

GPP was estimated as the sum of rates in light and dark incubations (GPP $=$ NPP + CR; Bott, 2006). Productionto-respiration ratio $(\mathrm{P} / \mathrm{R})$ describes the balance of metabolic processes during $24 \mathrm{~h}$ period and was calculated as GPP converted to daily metabolism divided by the CR during $24 \mathrm{~h}$ period following the equation: $\mathrm{GPP} / \mathrm{CR}_{24}$ (Bott, 2006).

Pre- and post-incubation water samples were collected to assess nutrient depletion within chambers during incubations [nitrite $\left(\mathrm{NO}_{2}^{-}-\mathrm{N}\right)$, ammonium $\left(\mathrm{NH}_{4}^{+}-\mathrm{N}\right)$ and phosphate $\left.\left(\mathrm{PO}_{4}-\mathrm{P}\right)\right]$. Nutrient analyses were done on a MERCK Spectroquant Nova 60, using Spectroquant ${ }^{\circledR}$ Test kits for $\mathrm{NO}_{2}^{-}, \mathrm{NH}_{4}^{+}$and $\mathrm{PO}_{4}^{2-}$. To validate oxygen readings taken by the $\mathrm{DO}$ probe, we simultaneously collected water samples for oxygen analysis, using the spectrophotometric Winkler method (Labasque et al., 2004).

Simultaneously with oxygen measurements, temperature inside the chamber was monitored (using the YSI probe model) as well as PAR in $\mu$ mol quanta $\mathrm{m}^{-2} \cdot \mathrm{s}^{-1}$ (LI-250A Light Meter). The light sensor was placed in the water in the proximity of chambers to ensure that the amount of light that reach the sensor was the same that reach the chambers. Current velocity $\left[\mathrm{m} . \mathrm{s}^{-1}\right]$ in each habitat type used for the experiment was measured using a two-dimensional acoustic-Doppler velocimeter (FlowTracker Handheld ADV, Sontek YSI Inc.). After the experiment finished, the content of each chamber was taken to the laboratory and processed for determination of periphyton biomass and macroinvertebrate identification.

We scrubbed periphyton from stones and leaves into a known volume of water using a toothbrush (Biggs and Kilroy, 2000). In case of LL, each piece of leave material was gently placed in the tray and superficial biofilm layer was scrubbed from both sites. The resultant slurry was thoroughly homogenized, subsampled and filtered on glass fibre filters $(\mathrm{GF} / \mathrm{C}, 47 \mathrm{~mm}$ Whatman) for determinations 
of chlorophyll $a\left(\mathrm{Chl} a \mathrm{mg} \cdot \mathrm{m}^{-2}\right.$ ) and AFDM (mg.m ${ }^{-2}$ ). AFDM of LL was measured separately including all the leaves biomass. Chl $a$ was extracted in $90 \%$ boiling ethanol and kept in the freezer for $24 \mathrm{~h}$. The absorbance was read on spectrophotometer (Thermospectronic GENESYS 10UV). AFDM filters were dried at $60^{\circ} \mathrm{C}$ to constant weight and AFDM represents the weight difference before and after $4 \mathrm{~h}$ at $450^{\circ} \mathrm{C}$ (Biggs and Kilroy, 2000).

For AFDM analyses in the chambers containing LL, all the biomass was collected, placed on the tray, dried and ashed as described above. For the chambers containing cobbles and cobbles covered with algae, Chl $a$ and AFDM were calculated per stone surface area assuming that metabolically active area of stones is 60\% (Biggs and Close, 1989).

Macroinvertebrates from each chamber were sorted and identified to family level (except Ostracoda and Oligochaeta). In order to verify whether the macroinvertebrate assemblages inside the chambers reflected the macroinvertebrate assemblages collected using kick sampling method (with hand net of $0.5 \mathrm{~mm}$ mesh and $25 \mathrm{~cm}$ width), we compared data from the chambers and from routine sampling done previously on the same type of habitats (Sroczyńska et al., 2014).

\section{Data analysis}

We compared ecosystem metabolism among habitats with analysis of variance (ANOVA) when assumptions of normality (Shapiro-Wilk test for small sample size) and homogeneity of variance (Leven's test) were met. When the homogeneity of variance assumption was not met, we applied the non-parametric Kruskal-Wallis Rank Sum Test using the "kruskalmc" function in the R package "pgirmess" (R Development Core Team, 2012; Giraudoux, 2013). We performed Tukey's post hoc analyses and generated $95 \%$ confidence intervals using the "TukeyHSD" function in the R package "multcomp" (Hothorn et al., 2008; R Development Core Team, 2012). Univariate analyses and graphs were done using R package ( $\mathrm{R}$ Development Core Team, 2012). When ANOVA demonstrated significant differences between habitats, correlation analysis were done, treating each habitat separately. Spearman product moment correlation was used to assess the relationship between explanatory and response variables as well as correlation between DO measurements and Winkler spectrophotometry oxygen determination.

Multivariate analyses were performed on normalized (Euclidean distances) metabolic responses (NPP, GPP and $\mathrm{CR}$ ) and explanatory variables (Chl $a$, AFDM, VR, PAR, temp, nitrite, phosphate and ammonium), with habitat as a fixed factor. PERMANOVA (permutational multivariate analysis of variance) was used to test for significant differences in metabolism between the habitats. Distancebased linear models (DistLM) were used to examine the relationship between response variables and explanatory variables. Firstly, the significance of the relationship was assessed for individual environmental variables with marginal tests (999 permutations). Significant variables $(P<0.01)$ were subsequently included in model selection using the BEST procedure, which tests all possible combinations between explanatory variables and the response matrix. This procedure helps eliminate the effect of covariance between the variables, as it considers all the response variables together. Distance-based redundancy analysis (dbRDA) was used for the ordination and visualization of the best overall DistLM solution, according to the Akaike information criterion (AIC). All multivariate analyses were done using the PRIMER 6 statistical package with the PERMANOVA + add-on (Clarke and Warwick, 2001).

\section{Results}

\section{Benthic metabolism}

The highest significant average GPP was recorded for the habitat $\mathrm{C}+\mathrm{A}$ and the lowest for the habitat $\mathrm{C}$ (Fig. 1, Table 1). Average oxygen consumption (CR) during dark phase was 3-fold and 7-fold higher in habitat LL, relative to $\mathrm{C}+\mathrm{A}$ and $\mathrm{C}$, respectively (Fig. 1). The variability in oxygen consumption during dark phase in $\mathrm{C}$ and $\mathrm{C}+\mathrm{A}$ was lower than during light hours, while LL habitat demonstrated high variation in both respiration rate and oxygen production. All three habitats show significant differences in terms of GPP, NPP and CR (Table 2). For NPP and GPP variables, Tukey multi pairwise comparisons showed significant differences between $\mathrm{C}+\mathrm{A}-\mathrm{C}$ $(P<0.001)$ and $\mathrm{C}+\mathrm{A}-\mathrm{LL}(P<0.001)$, but not for $\mathrm{LL}-$ C $(P=0.32$ and $P=0.25$ respectively). Multiple comparisons after Kruskal-Wallis for CR showed significant differences $(P<0.05)$ among all the groups.

Autotrophy dominated in $\mathrm{C}+\mathrm{A}$ and $\mathrm{C}$ habitats, with positive $\mathrm{P} / \mathrm{R}$ ratios $(>1)$, while $\mathrm{LL}$ was entirely heterotrophic $(\mathrm{P} / \mathrm{R}<1$; Fig. 1, Table 1$)$. The highest mean production relatively to respiration was recorded for the $\mathrm{C}+\mathrm{A}$ habitat (3.13) and the lowest for LL (0.49).

\section{Environmental variables}

Chl $a$ ranged from 1 to $33 \mathrm{mg} \cdot \mathrm{m}^{-2}$ on $\mathrm{C}$ habitat, 21 to $146 \mathrm{mg} \mathrm{m}^{-2}$ on $\mathrm{C}+\mathrm{A}$ habitat and $9-64 \mathrm{mg} \cdot \mathrm{m}^{-2}$ on LL (Table 3). The highest average Chl $a$, as well as the highest variability, was measured in habitat $\mathrm{C}+\mathrm{A}$ and the lowest in habitat C. LL had twice the average Chl $a$ than $\mathrm{C}$ habitat. AFDM ranged from 1 on $\mathrm{C}$ to $36 \mathrm{~g} \cdot \mathrm{m}^{-2}$ on $\mathrm{C}+\mathrm{A}$, while values in LL habitat were two orders of magnitude higher than in the other habitats and showed a broad variation (900-1921 g.m ${ }^{-2}$ ). Temperature varied little between habitats, with average of $21-22{ }^{\circ} \mathrm{C}$. Water flow passing through the chambers varied on a narrow interval $\left(0.06 \pm 0.005 \mathrm{~m}^{3} \cdot \mathrm{h}^{-1}\right)$ and it did not differ among habitats. 

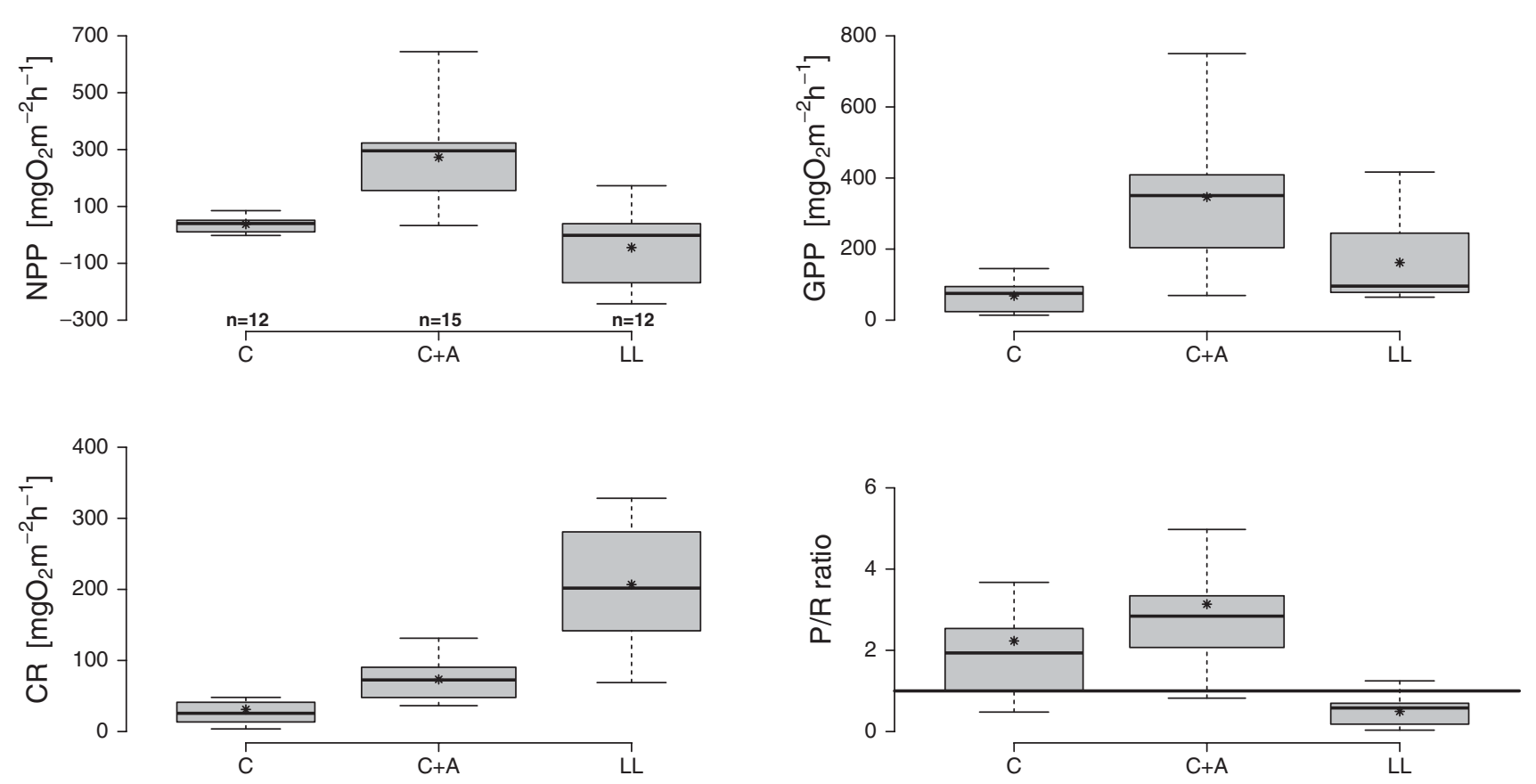

Fig. 1. Boxplots with NPP, GPP, CR and P/R ratio for each habitat; where black asterisk is a mean; horizontal segment is a median; horizontal lines marking the box are first and third quartiles with "whiskers" that extends to minimum and maximum value. Horizontal line in $\mathrm{P} / \mathrm{R}$ ratio boxplot marks the benchmark for autotrophy $(>1)$ and heterotrophy $(<1)$.

Table 1. Range for net primary production (NPP), gross primary production (GPP), community respiration, $\left.\mathrm{CR}^{\mathrm{g}} \mathrm{g}_{2} \mathrm{~m}^{2} . \mathrm{day}{ }^{-1}\right]$ and $\mathrm{P} / \mathrm{R}$ ratio for each habitat $(\mathrm{C}$, cobble; $\mathrm{C}+\mathrm{A}$, cobble covered by algae; $\mathrm{LL}$, leaf litter).

\begin{tabular}{lrrrr}
\hline Habitat & NPP & GPP & CR & P/R ratio \\
\hline C & $-0.03-1.22$ & $0.17-1.93$ & $0.086-1.94$ & $0.48-7.72$ \\
C + A & $0.47-8.66$ & $0.99-9.84$ & $0.64-2.55$ & $0.82-9.14$ \\
LL & $-3.86-2.47$ & $0.23-5.99$ & $1.65-7.87$ & $0.03-1.25$ \\
\hline
\end{tabular}

Nutrients varied little between measurements and paired $t$-test showed no significant differences in nitrites and phosphates between pre- and post- water samples for both light and dark incubations $(P>0.05)$. Ammonium levels were mostly below the detection limits of our instrumentation $\left(<0.05 \mathrm{mg} . \mathrm{L}^{-1}\right)$.

Correlation between the DO probe and Winkler spectrophotometric determination was very high $(r=0.86$, $P<0.001$ ), with consistently lower values obtained by Winkler spectrophotometry $\left(3.2-18.0 \mathrm{mg} \mathrm{O} \mathrm{O}_{2} \cdot \mathrm{L}^{-1}\right)$ than measured by the oxygen probe $\left(4.2-22.0 \mathrm{mg} \mathrm{O}_{2} \cdot \mathrm{L}^{-1}\right)$.

\section{Relationship between benthic metabolism and habitat characteristics}

The best DistLM model provided by BEST procedure included three vector overlays: Chl $a$, AFDM and PAR, which significantly contributed to the ordination axes (Fig. 2). The model explained over $60.0 \%$ of the total variability in data. From these three vectors, Chl $a$ and AFDM were the strongest contributors to the dbRDA analysis, having higher explanatory potential in comparison with PAR. The variation in Chl $a$ and PAR were associated with the variation in NPP and GPP in C + A habitat, while AFDM was strongly associated with LL habitat and strongly correlated with CR.

PERMANOVA showed statistically significant differences in explanatory variables among all the habitats ( $F=21.6, P=0.001$, based on 999 permutations) and pairwise tests showed that LL habitat differed the most from the other two habitats, with higher dissimilarity between LL and C $+\mathrm{A}$ than LL and C. Due to differences existing between all three habitats, correlation analyses were performed separately for each habitat.

Both $\mathrm{C}$ and $\mathrm{C}+\mathrm{A}$ habitats displayed decrease of production efficiency (expressed as GPP/Chl $a$ ratio) with increasing standing stock (AFDM, Table 4). Chlorophyll $a$ concentration was positively correlated with oxygen consumption (CR) in $\mathrm{C}+\mathrm{A}$ and LL habitats (Table 4), although not in $\mathrm{C}$ habitat. High correlation existed between primary production and oxygen consumption in $\mathrm{C}$ and $\mathrm{C}+\mathrm{A}$ habitats. By contrast it was not the case in LL habitat, where no correlation existed between GPP and CR. GPP, NPP and production efficiency (GPP/Chl $a$ ratio) significantly increased with $\mathrm{PAR}$ in the $\mathrm{C}+\mathrm{A}$ habitat. In $\mathrm{C}$ habitat, temperature was positively correlated with GPP, NPP and CR, regardless of PAR, 
Table 2. Analysis of variance (ANOVA) for net primary production (NPP), gross primary production (GPP) and community respiration $(\mathrm{CR})$ for the differences between habitats.

\begin{tabular}{|c|c|c|c|c|c|c|c|c|c|}
\hline \multirow{2}{*}{\multicolumn{2}{|c|}{ Statistical test }} & \multicolumn{3}{|c|}{ ANOVA } & \multicolumn{3}{|c|}{ ANOVA } & \multirow{2}{*}{\multicolumn{2}{|c|}{$\begin{array}{c}\text { Kruskal-Wallis Rank Sum Test } \\
\mathrm{CR}\left(\mathrm{mg} \mathrm{O}_{2} \mathrm{~m}^{-1} \cdot \mathrm{h}^{-1}\right)\end{array}$}} \\
\hline & & GPP & $\mathrm{mg} \mathrm{O}_{2} \mathrm{~m}$ & '. $\left.\mathrm{h}^{-1}\right)$ & NPP & $\left(\mathrm{mg} \mathrm{O}_{2} \mathrm{~m}\right.$ & ..$\left.h^{-1}\right)$ & & \\
\hline Source of variation & $\mathrm{df}$ & Mean Sq. & $F$-ratio & $\operatorname{Pr}(>F)$ & Mean Sq. & $F$-ratio & $\operatorname{Pr}(>F)$ & $\chi^{2}$ & $\mathrm{P}$ \\
\hline Habitat & 2 & 272841.00 & 13.71 & $3.75 \times 10^{-}$ & 373635 & 19.96 & $1.47 \times 10^{-6}$ & 27.01 & $1.37 \times 10^{-6}$ \\
\hline Residual & 36 & 199.03 & & & 18719 & & & & \\
\hline
\end{tabular}

Table 3. Mean $\pm \mathrm{SE}$ for environmental variables (chlorophyll a, AFDM, photosynthetic active radiation, temperature, $\mathrm{PO}_{4}^{-}-\mathrm{P}$, $\mathrm{NO}_{2}-\mathrm{N}, \mathrm{NH}_{4}^{+}-\mathrm{N}$ ) and $\mathrm{GPP} / \mathrm{Chl}$ a measured during incubation experiments.

\begin{tabular}{|c|c|c|c|}
\hline \multirow[b]{2}{*}{ Measured variables } & \multicolumn{3}{|c|}{ Habitat type } \\
\hline & $\mathrm{C}$ & $\mathrm{C}+\mathrm{A}$ & LL \\
\hline Chlorophyll a (mg.m ${ }^{-2}$ ) & $9.95 \pm 3.09$ & $76.13 \pm 10.45$ & $22.55 \pm 4.47$ \\
\hline $\operatorname{AFDM}\left(\mathrm{g} \cdot \mathrm{m}^{-2}\right)$ & $5.02 \pm 1.15$ & $17.00 \pm 2.10$ & $1382 \pm 94.99$ \\
\hline $\operatorname{PAR}\left(\mu \mathrm{E} \mathrm{m}{ }^{-2} \cdot \mathrm{s}^{-1}\right)$ & $1799 \pm 110$ & $1495 \pm 181$ & $1554 \pm 186$ \\
\hline Temperature $\left({ }^{\circ} \mathrm{C}\right)$ & $21.51 \pm 0.55$ & $22.57 \pm 0.37$ & $21.68 \pm 0.46$ \\
\hline $\mathrm{PO}_{4}-\mathrm{P}\left(\mathrm{mg} \mathrm{L}^{-1)}\right)$ & $0.046 \pm 0.003$ & $0.048 \pm 0.005$ & $0.041 \pm 0.003$ \\
\hline $\mathrm{NO}_{2}-\mathrm{N}\left(\mathrm{mg} . \mathrm{L}^{-1}\right)$ & $0.042 \pm 0.009$ & $0.035 \pm 0.006$ & $0.036 \pm 0.007$ \\
\hline $\mathrm{NH}_{4}{ }^{+}-\mathrm{N}\left(\mathrm{mg} \cdot \mathrm{L}^{-1}\right)$ & $0.30 \pm 0.27$ & $0.31 \pm 0.21$ & $0.33 \pm 0.26$ \\
\hline $\mathrm{GPP} / \mathrm{Chl}$ a ratio & $13.70 \pm 2.97$ & $5.51 \pm 1.03$ & $8.15 \pm 1.34$ \\
\hline
\end{tabular}
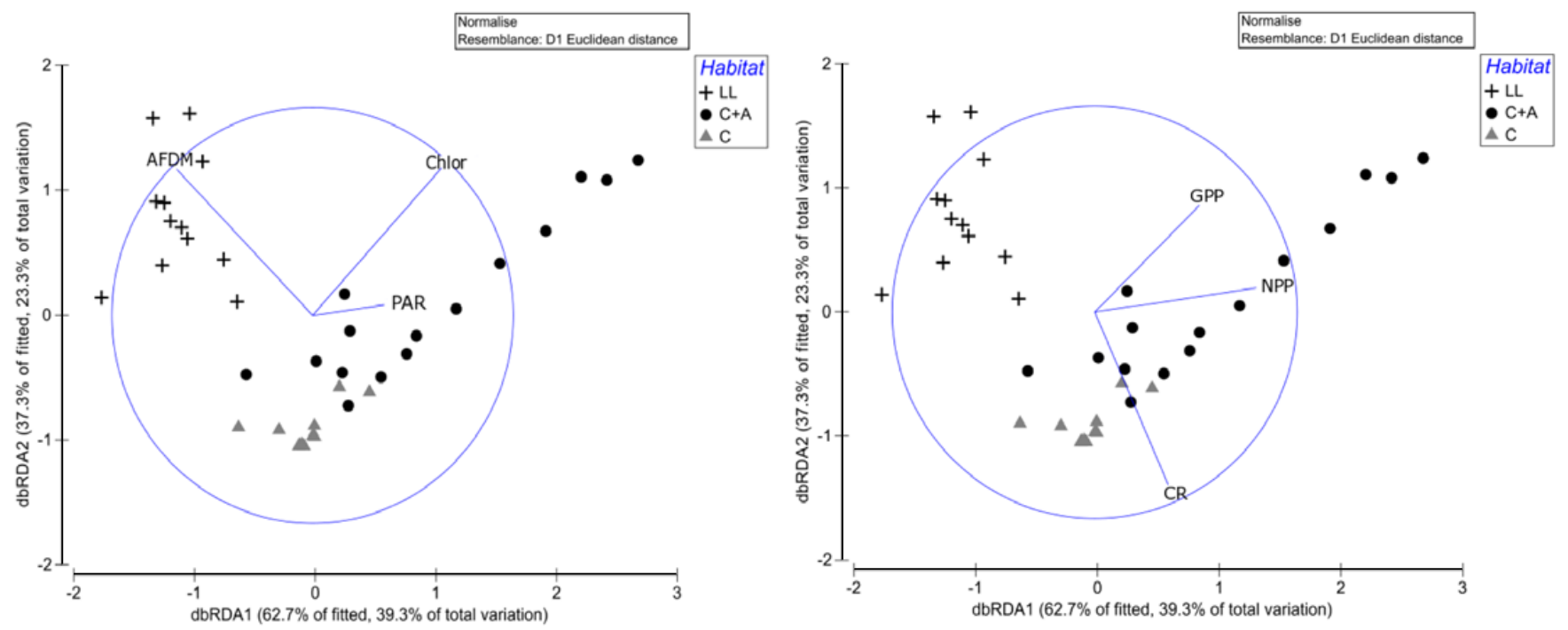

Fig. 2. Diagram of distance-based redundancy analysis (dbRDA) for the best distance-based linear models (DistLM) solution. Vector overlays represent significant variables included in the model, selected with the BEST procedure based on Akaike's information criterion. Left panel represents explanatory variables and right panel the response variables. Lengths of vectors indicate the relative influence of each variable for the ordination.

which was not significantly correlated with any of these variables.

\section{Discussion}

Results were consistent with our predictions, in that all three habitats showed positive gross primary production, but with significantly higher net oxygen production in cobble and cobble covered with algae. Half of the LL habitat patches exhibited negative NPP, indicating that oxygen was consumed more rapidly than it was produced. The LL habitat was an important site for high microbial activity, however, it constituted less than $10 \%$ of overall benthic substrate and thus its contribution at the reachscale is probably limited. Accordingly, during stabilized flow conditions, benthic metabolism was dominated by net autotrophy, in cobble and cobble covered by algae habitats, with localized heterotrophy in LL.

Physical substrate heterogeneity and biological characteristics of substrata were demonstrated to influence both GPP and CR ratio (Guash et al., 1995; Sabater and Romani, 1996; Sabater et al., 1998; Cardinale et al., 2002; Clapcott and Barmuta, 2010). Similar range of GPP and $\mathrm{CR}$ values, measured using open-channel and metabolic chamber methods were obtained in other Mediterranean 
Table 4. Spearman's rank correlation for the response and independent variables.

\begin{tabular}{|c|c|c|c|c|c|c|c|c|}
\hline Habitat & Variable & NPP & GPP & CR & Chl a & AFDM & PAR & Temp \\
\hline \multirow[t]{4}{*}{$\mathrm{C}$} & NPP & & $0.82 * * *$ & 0.31 & $0.73 * * *$ & 0.55 & -0.36 & $0.62 * *$ \\
\hline & GPP & & & $0.76 * * *$ & $0.60 * *$ & 0.52 & -0.24 & $0.73 * *$ \\
\hline & $\mathrm{CR}$ & & & & 0.45 & 0.48 & -0.20 & $0.66 * *$ \\
\hline & GPP/Chl a & -0.41 & -0.09 & -0.06 & $-0.81 * * *$ & $-0.62 * *$ & 0.39 & -0.31 \\
\hline \multirow[t]{4}{*}{$\mathrm{C}+\mathrm{A}$} & NPP & & $0.95 * * *$ & 0.44 & 0.31 & -0.38 & $0.78 * * *$ & 0.10 \\
\hline & GPP & & & $0.65 * * *$ & $0.51 * *$ & 0.28 & $0.73 * * *$ & 0.16 \\
\hline & $\mathrm{CR}$ & & & & $0.75 * * *$ & 0.16 & 0.37 & 0.28 \\
\hline & GPP/Chl a & $0.73^{*}$ & $0.60 * *$ & 0.08 & 0.35 & $-0.70 * * *$ & $0.65 * * *$ & -0.16 \\
\hline \multirow[t]{4}{*}{ LL } & NPP & & $0.89 * * *$ & -0.38 & 0.13 & 0.10 & 0.21 & -0.08 \\
\hline & GPP & & & -0.14 & 0.22 & 0.16 & 0.06 & 0.15 \\
\hline & CR & & & & $0.59 * *$ & 0.29 & -0.53 & 0.48 \\
\hline & GPP/Chl a & $0.68 * *$ & $0.76 * * *$ & 0.31 & -0.36 & 0.09 & 0.43 & 0.03 \\
\hline
\end{tabular}

Significant codes are as: $<0.01 * * *,<0.05 * *$.

ecosystems (Molla et al., 1994, 1996, Suárez and VidalAbarca, 2000; Aristegi et al., 2010) and in desert streams (Busch and Fisher, 1981; Grimm and Fisher, 1984; Mulholland et al., 2001). Molla et al. (1994) obtained similar values of GPP (3.24 $\mathrm{g} \mathrm{O}_{2} \mathrm{~m}^{2}$.day $\left.{ }^{-1}\right)$, but higher average values of respiration $\left(2.9 \mathrm{~g} \mathrm{O}_{2} \mathrm{~m}^{2}\right.$.day $\left.{ }^{-1}\right)$ for periphyton communities, using dial oxygen curve method. Our estimates of GPP and CR are most similar to the results obtained by Suárez and Vidal-Abarca (2000) for whole periphyton communities by using diurnal oxygen change method (range 0.24-10.7 for GPP and 0.26-7.29 g $\mathrm{O}_{2} \mathrm{~m}^{2}$.day ${ }^{-1}$ for CR). Aristegi et al. (2010) reported wide ranges of GPP $\left(0-35.3 \mathrm{~g} \mathrm{O}_{2} \mathrm{~m}^{2}\right.$.day $\left.{ }^{-1}\right)$ and CR (1.1-17.2 g $\mathrm{O}_{2} \mathrm{~m}^{2}$.day ${ }^{-1}$ ) using recirculatory chambers. However, their study encompassed streams with large variability in environmental conditions, whereas the small ranges of GPP and CR in our study were measured in only one reach. Similar values were also reported for a desert stream by Mulholland et al. (2001) (3.0 for GPP and 8.3 for CR g $\mathrm{O}_{2} \mathrm{~m}^{2}$.day ${ }^{-1}$ ), using two-station diurnal oxygen change method. Accordingly, our results with metabolic chambers on $\mathrm{C}$ and $\mathrm{C}+\mathrm{A}$ habitats are consistent with previous studies in intermittent streams in regions of Mediterranean and semiarid climate.

\section{Primary production}

Previous studies found that algae production increases with the Chl a standing crop (Morin et al., 1999; Bernot et al., 2010). Similarly, we found that the most productive cobble covered with algae had the highest Chl $a$ concentration compared to other habitats. A positive effect of algae biomass on GPP has been reported across different regions, as measured by open channel methods (Bott et al., 1985; Morin et al., 1999; Bernot et al., 2010). However, high periphyton biomass does not necessarily translate into higher production efficiency (as seen from the results of GPP/Chl-a ratio) and also reported by Velasco et al. (2003). Decrease of GPP/Chl $a$ ratio with increasing standing stock of periphyton is common for stream ecosystems (Guash et al., 1995; Morin et al., 1999; Velasco et al.,
2003). This pattern can be related to different composition of the algal assemblages and biofilm thickness in cobble and cobble covered by algae habitats. Shifts in algae community along the gradient of biofilm development are well documented (Hudon and Bourget, 1983; Sabater and Romani, 1996). In our study, the biofilm in C + A habitat was dominated by green filamentous algae, while the biofilm in the cobble habitat was scarce and nearly invisible. Phytoplankton photosynthetic rates are known to decrease with the increasing cell wall thickness (Enríquez et al., 1996) and therefore, thicker walls of filamentous algae in $\mathrm{C}+\mathrm{A}$ habitat were potentially responsible for the negative trend between GPP/Chla and periphyton biomass. Another contributory mechanism that could explain this pattern is self-shading, which is a common process associated with periphyton of well-developed and complex biofilm structures (Guash et al., 1995).

PAR was found to be positively correlated with GPP among different reaches, in open channel measurements (Bott et al., 1985; Mulholland et al., 2001; Acuna et al., 2004; Bernot et al., 2010) as well as incubation chambers, considering only epilithic assemblages (Velasco et al., 2003) and whole communities (Rosenfeld and Roff, 1991). By contrast, in our study PAR explained very little variation in metabolic parameters and had distinct influence on primary production for different habitats (Table 4). Lack of correlation between PAR and cobble is corroborated by the low levels of chlorophyll $a$ on this habitat. Interestingly, temperature independently of PAR was positively correlated with GPP on cobble, but not on cobble covered with algae. This additionally confirms that biofilm structure has important role in regulating GPP response in this temporary stream.

Primary production in LL was greater than in cobble. These differences appear to be driven by distinct substrate characteristics of $\mathrm{C}$ and LL. Organic conditioning of litter enhances algae GPP by allowing the use of the underlying substratum as a nutrient source (Sabater et al., 1998). Additionally, the oligotrophic nature of our study stream could exacerbate the nutrient limitation effect on algal colonization of cobbles. It is important to mention, however, that GPP in LL habitat could have been 
overestimated, as the total area of leaves and remaining litter material probably exceeded the area of the chamber base.

\section{Community respiration}

The highest respiration was in the LL habitat. LL and woody substrata host greater amount of heterotrophic organisms, such as bacteria, fungi and macroinvertebrates, which utilize the underlying substratum to acquire nutrients and eventually contribute to organic matter decomposition (Graça et al., 2001; Romaní and Sabater, 2001; Gulis and Suberkropp, 2003). In our study, AFDM (detrital standing crop) was responsible for variation in $\mathrm{CR}$ and differentiated the heterotrophic LL habitat, with large amounts of AFDM, from other two habitats, with smaller values of AFDM (RDA analyses). When we examined only the LL habitat, however, litter biomass did not contribute to the variation in community respiration. This lack of correlation is presumably because CR in LL is fuelled by a combination of heterotrophic utilization of the allochthonous organic matter itself, but also some contribution of microbial and algal respiration associated with periphyton. Leaves used for the experiment were senescent and the long period in the water allowed microorganisms to be associated with leaf mesophyll as well as create a layer of biofilm on their surface. Additionally, the main groups of macroinvertebrates were collectorgatherers and scrapers, with only few shredders, which confirm the trophic potential of the biofilm. However, the short acclimation time of base units in the stream did not allow proper colonization of macroinvertebrates, in comparison with benthic community encountered in this habitat during conventional sampling with hand net. Base units had more mobile and drifting taxa and less burrowing organisms. Accordingly, some important burrowing shredders, such as Diptera family, may have been under represented.

In contrast, the cobble habitat had the lowest CR from all the habitats studied and, although the average Chl $a$ concentration in LL was only twice higher than in C habitat, CR in LL was almost 7-fold higher than in cobble. Therefore, higher respiration in LL is likely a result of heterotrophic activity and microbial respiration associated with biofilm layer, rather than autotrophic respiration. The organic nature of leaves promotes settlement of fungi and bacteria, which obtain nutrients via LL degradation. In contrast, the major part of respiration in cobble and cobble covered by algae habitats came from autotrophic respiration, which is also reflected in high correlation between GPP and CR in these habitats.

\section{Conclusions}

Most metabolism studies with benthic chambers focus only on the dominant habitat type in a river reach (Whitledge and Rabeni, 2000; Rees et al., 2005; Aristegi et al., 2010). Our study clearly emphasizes that extrapolating from a single habitat to the entire reach or stream will result in significant under or over estimation of the metabolic rates, depending on the proportional dominance of habitat types. For example, benthic habitat mapping of the reach used in our study, done in previous years, indicated striking differences in habitat coverage between winter (5\% of algae cover) and summer $(50 \%$ of algae cover, Wasiak et al., 2013). Considering that, during summer, at least half of the substrate in intermittent Mediterranean streams is covered by filamentous algae, using only the cobble substrate for incubations would underestimate GPP by $67 \%$. Accordingly, scaling up measurements from discrete habitats to the entire reach or stream requires quantification of habitat coverage. This can be achieved by the use of various techniques such as GIS-based analysis, based on visual benthic habitat mapping, for small reaches, or side scan sonar imagery to map larger areas of streams to whole catchments.

Employment of flow cell into chamber design successfully overcame two main drawbacks related to chamber metabolism measurements: bubble formation and inadequate water circulation within chambers (Bott et al., 1997; Dodds and Brock, 1998; Uzarski et al., 2001). Furthermore, measurements taken by DO oxygen probe are linearly related to the oxygen concentrations measured using the Winkler method. This validates the use of in situ DO probes to monitor oxygen concentration during the incubation experiments and the accurateness of the metabolic rates obtained by this improved chamber design.

Acknowledgements. The authors acknowledge David Harper, Victor Garcia Lopez, Carlos Sanchez Ureña, Almudena López Fernández and Bogna Jacniacka for their contribution to experimental design and field work. We are also grateful to Tanner Williamson and Jennifer Taylor for their comments on the manuscript and English review. The authors also acknowledge anonymous referee for their valuable comments, which contributed to the manuscript improvement. This work was a part of the IMPACT project, funded by Foundation for Science and Technology (FCT) of Portugal (ER-IWRM/0003/2009). F. Leitão was also funded by a scholarship from FCT (Reference SFRH/BPD/63935/2009).

\section{References}

Acuna V., Giorgi A., Muñoz I., Uehlinger U.R.A. and Sabater S., 2004. Flow extremes and benthic organic matter shape the metabolism of a headwater Mediterranean stream. Freshwat. Biol., 49, 960-971.

Aristegi L., Izagirre O. and Elosegi A., 2010. Metabolism of Basque streams measured with incubation chambers. Limnetica, 29, 301-310.

Armitage P.D. and Cannan C.E., 2000. Annual changes in summer patterns of mesohabitat distribution and associated macroinvertebrate assemblages. Hydrol. Process., 14, 3161-3179.

Beisel J., Usseglio-polatera P., Thomas S. and Moreteau J., 1998. Stream community structure in relation to spatial 
variation: the influence of mesohabitat characteristics. Hydrobiologia, 389, 73-88.

Beisel J.N., Usseglio-Polatera P. and Moreteau J.C., 2000. The spatial heterogeneity of a river bottom: a key factor determining macroinvertebrate communities. Hydrobiologia, 422/423, 163-171.

Bernot M.J., Sobota D.J., Hall R.O., Mulholland P.J., Dodds W.K. and Webster J.R., 2010. Inter-regional comparison of land-use effects on stream metabolism. Freshwat. Biol., 55, 1874-1890.

Biggs B.J.F. and Close M.E., 1989. Periphyton biomass dynamics in gravel bed rivers: the relative effects of flows and nutrients. Freshwat. Biol., 22, 209-231.

Biggs B.J.F. and Kilroy C., 2000. Stream Periphyton Monitoring Manual, Published for NZ Ministry for the Environment by NIWA, Christchurch, 76-91.

Bott T.L., 2006. Primary production and community respiration. In: Hauer F.R. and Lamberti G.A. (eds.), Methods in Stream Ecology (2nd edn), Academic Press, Burlington, MA, 663-690.

Bott T.L., Brock J.T., Cushing C.E., Gregory S.V., King D. and Petersen R.C., 1978. A comparison of methods for measuring primary productivity in streams. Hydrobiologia, 60, 3-12.

Bott T.L., Brock J.T., Dunn C.S., Naiman R.J., Ovink R.W. and Petersen R.C., 1985. Benthic community metabolism in four temperate streams: an inter-biome comparison and evaluation of the river continuum concept. Hydrobiologia, $123,3-45$.

Bott T.L., Brock J.T., Baattrup-Pedersen A., Chambers P.A., Dodds W.K., Himbeault K.T., Lawrence J.R., Planas D., Snyder E. and Wolfaardt G.M., 1997. An evaluation of techniques for measuring periphyton metabolism in chambers. Can. J. Fish. Aquat. Sci., 54, 715-725.

Boyero L., 2003. The effect of substrate texture on colonization by stream macroinvertebrates. Ann. Limnol. - Int. J. Lim., 39, 211-218.

Brown B.L., 2003. Spatial heterogeneity reduces temporal variability in stream insect communities. Ecol. Lett., 6, 316-325.

Busch D.E. and Fisher S.G., 1981. Metabolism of a desert stream. Freshwat. Biol., 11, 301-307.

Cardinale B.J., Palmer M.A., Swan C.M., Brooks S. and Poff N.L., 2002. The influence of substrate heterogeneity on biofilm metabolism in a stream ecosystem. Ecology, 83, 412-422.

Clapcott J.E. and Barmuta L., 2010. Metabolic patch dynamics in small headwater streams: exploring spatial and temporal variability in benthic processes. Freshwat. Biol., 55, 806-824.

Clarke K.R. and Warwick R.M., 2001. Change in Marine Communities: An Approach To Statistical Analysis and Interpretation (2nd edn), PRIMER-E Ltd, Plymouth, UK.

Dodds W.K., 1991. Micro-environmental characteristics of filamentous algal communities in flowing freshwaters. Freshwat. Biol., 25, 199-209.

Dodds W.K. and Brock J., 1998. A portable flow chamber for in situ determination of benthic metabolism. Freshwat. Biol., 39, 49-59.

Elosegi A., Díez J. and Mutz M., 2010. Effects of hydromorphological integrity on biodiversity and functioning of river ecosystems. Hydrobiologia, 657, 199-215.

Enríquez S., Duarte C.M., Sand-Jensen K. and Nielsen S.L., 1996. Broad-scale comparison of photosynthetic rates across phototrophic organisms. Oecologia, 108, 197-206.

Fellows C.S., Clapcott J.E., Udy J.W., Bunn S.E., Harch B.D. and Smith M.J., 2006. Benthic Metabolism as an Indicator of Stream Ecosystem Health. Hydrobiologia, 572, 71-87.

Fuss C. and Smock L., 1996. Spatial and temporal variation of microbial respiration rates in a blackwater stream. Freshwat. Biol., 36, 339-349.

Gasith A. and Resh H.V., 1999. Streams in Mediterranean climate regions: abiotic influences and biotic responses to predictable seasonal events. Annu. Rev. Ecol. Evol. Syst., 30, 51-81.

Gessner M.O., Swan C.M., Dang C.K., McKie B.G., Bardgett R.D. and Wall D.H., 2010. Diversity meets decomposition. Trends Ecol. Evol., 25, 372-380.

Giraudoux P., 2013. pgirmess: Data analysis in ecology. R package version 1.5.8. http://CRAN.R-project.org/package $=$ pgirmess.

González Pinzón R., Haggerty R. and Argerich A., 2014. Quantifying spatial differences in metabolism in headwater streams. Freshwat. Sci., 33, 798-811. doi: 10.1086/677555

Graça M.A.S., Ferreira R.C.F. and Coimbra C.N., 2001. Litter processing along a stream gradient: the role of invertebrates and decomposers. J. N. Am. Benthol. Soc., 20, 408-420.

Grimm N.B. and Fisher S.G., 1984. Exchange between interstitial and surface water: implications for stream metabolism and nutrient cycling. Hydrobiologia, 111, 219-228.

Guash H., Martí E. and Sabater S., 1995. Nutrient enrichment effects on biofilm metabolism in a Mediterranean stream. Freshwat. Biol., 33, 373-383.

Gulis V. and Suberkropp K., 2003. Leaf litter decomposition and microbial activity in nutrient-enriched and unaltered reaches of a headwater stream. Freshwat. Biol., 48, 123-134.

Gustafson E.J., 1998. Quantifying landscape spatial pattern: what is the state of the art? Ecosystems, 1, 143-156.

Hothorn T., Bretz F. and Westfall P., 2008. Simultaneous inference in general parametric models. Biomet. J., 50, 346-363.

Hudon C. and Bourget E., 1983. The effect of light on the vertical structure of epibenthic diatom communities. Bot. Mar., 26, 317-330.

Labasque T., Chaumery C., Aminot A. and Kergoat G., 2004. Spectrophotometric Winkler determination of dissolved oxygen: re-examination of critical factors and reliability. Mar. Chem., 88, 53-60.

Lepori F., Palm D., Brännäs E. and Malmqvist B., 2005. Does restoration of structural heterogeneity in streams enhance fish and macroinvertebrate diversity? Ecol. Appl., 15, 2060-2071.

Marzolf E.R., Mulholland P.J. and Steinman A.D., 1994. Improvements to the diurnal upstream-downstream dissolved oxygen change technique for determining wholestream metabolism in small streams. Can. J. Fish. Aquat. Sci., 51, 1591-1599.

Molla S., Malchik L. and Casado C., 1994. Primeros datos sobre el metabolismo de un arroyo temporal mediterráneo de Sierra Morena (Córdoba). Limnetica, 10, 59-67.

Molla S., Maltchik L., Casado C. and Montes C., 1996. Particulate organic matter and ecosystem metabolism dynamics in a temporary Mediterranean stream. Arch. Hydrobiol., 137, 59-76.

Morin A., Lamoureux W. and Busnarda J., 1999. Empirical models predicting primary productivity from chlorophyll $a$ 
and water temperature for stream periphyton and lake and ocean phytoplankton. J. N. Am. Benthol. Soc., 18, 299-307.

Mulholland P.J., Fellows C.S., Tank J.L., Grimm N.B., Webster J.R., Hamilton S.K. and Peterson B.J., 2001. Inter-biome comparison of factors controlling stream metabolism. Freshwat. Biol., 46, 1503-1517.

O'Connor N.A., 1991. The effects of habitat complexity on the macroinvertebrates colonising wood substrates in a lowland stream. Oecologia, 85, 504-512.

Odum H.T., 1956. Primary production in flowing waters. Limnol. Oceanogr., 1, 102-117.

Oliveira V.C., Gonçalves, E.A. and Alves R.G., 2014. Colonisation of leaf litter by aquatic invertebrates in an Atlantic Forest stream. Braz. J. Biol., 74, 267-273.

Palmer M.A. and Poff N.L., 1997. The influence of environmental heterogeneity on patterns and processes in streams. J. N. Am. Benthol. Soc., 16, 169-173.

Poff N.L. and Ward J.V., 1989. Implications of streamflow variability and predictability for lotic community structure: a regional analysis of streamflow patterns. Can. J. Fish. Aquat. Sci., 46, 1805-1818.

Pringle C.M., Naiman R.J., Bretschko G., Karr J.R., Oswood M.W., Webster J.R., Welcomme R.L. and Winterbourn M.J., 1988. Patch dynamics in lotic systems: the stream as a mosaic. J. N. Am. Benthol. Soc., 7, 503-524.

Rabeni C.F. and Minshall G.W., 1977. Factors affecting microdistribution of stream benthic insects. Oikos, 29, 33-43.

R Core Team (2012) R: A language and environment for statistical computing. R Foundation for Statistical Computing, Vienna, Austria. URL http://www.R-project.org/.

Rees G.N., Bowen P.M. and Watson G.O., 2005. Variability in benthic respiration in three southeastern Australian lowland rivers. River Res. Appl., 21, 1147-1156.

Rier S.T. and King D.K., 1996. Effects of inorganic sedimentation and riparian clearing on benthic community metabolism in an agriculturally-disturbed stream. Hydrobiologia, 339, 111-121.

Romaní A.M. and Sabater S., 2001. Structure and activity of rock and sand biofilms in a Mediterranean stream. Ecology, 82, 3232-3245.

Rosenfeld J. and Roff J.C., 1991. Primary production and potential availability of autochthonous carbon in southern Ontario streams. Hydrobiologia, 224, 99-109.

Sabater S. and Romaní A.M., 1996. Metabolic changes associated with biofilm formation in an undisturbed Mediterranean stream. Hydrobiologia, 335, 107-113.

Sabater S., Gregory S.V. and Sedell J.R., 1998. Community dynamics and metabolism of benthic algae colonizing wood and rock substrata in a forest stream. J. Phycol., 34, 561-567.
Southwood T.R.E., 1977. Habitat, the templet for ecological strategies? J. Anim. Ecol., 46, 337-365.

Sroczyńska K., Claro M., Range P., Ben-Hamadou R., Wojtal-Frankiewicz A. and Chícharo L., 2014. Substratum preferences of macroinvertebrates in a Mediterranean-type intermittent river: a tool to predict habitat suitability under future scenarios of climatic change, Conference on European Climate Change Adaptation - Research and Practice, Lisbon, Portugal from 10-12 March 2014. lower C:N and $\mathrm{C}: \mathrm{P}$ ratios.

Suárez M.L. and Vidal-Abarca M.R., 2000. Metabolism of a semi-arid stream of south-east Spain. Verh. Internat. Verein. Theor. Angew. Limnol., 27, 756-761.

Townsend C.R. and Hildrew A.G., 1994. Species traits in relation to a habitat templet for river systems. Freshwat. Biol., 31, 265-275.

Trindade M.J., Rocha F., Dias M.I. and Prudêncio M.I., 2013. Mineralogy and grain-size distribution of clay-rich rock units of the Algarve Basin (South Portugal). Clay Miner., 48, 59-83.

Uzarski D.G., Burton T.M. and Stricker C.A., 2001. A new chamber design for measuring community metabolism in a Michigan stream. Hydrobiologia, 455, 137-155.

Velasco J., Millan A., Vidal-Abarca M.R., Suarez M.L., Guerrero C. and Ortega M., 2003. Macrophytic, epipelic and epilithic primary production in a semiarid Mediterranean stream. Freshwat. Biol., 48, 1408-1420.

Wallace J.B., Eggert S.L., Meyer J.L. and Webster J.R., 1997. Multiple trophic levels of a forest stream linked to terrestrial litter inputs. Science, 277, 102-104.

Warnaars T.A., Hondzo M. and Power M.E., 2007. Abiotic controls on periphyton accrual and metabolism in streams: scaling by dimensionless numbers. Water Resour. Res., 43, $1-13$.

Wasiak K.A., 2009. Studies on the Effect of Phosphorus upon Headwater Stream Ecosystem Processes, PhD dissertation, Department of Biology, University of Leicester, Leicester LE1 7RH, UK.

Wasiak K., Sroczyńska K., Claro M., Range P., Ben-Hamadou R., Wojtal-Frankiewicz A., and Chícharo L., 2013. Metabolic response of aquatic communities to seasonal changes in environmental variables in a Mediterranean-type intermittent river. In: Conf. on Ecohydrology, Biotechnology \& Engineering, Towards the Harmony between Biogeosphere and Society on the basis of Long Term Ecosystem Research, Łódź, Poland from 16-19 September 2013.

Whitledge G.W. and Rabeni C.F., 2000. Benthic community metabolism in three habitats in an Ozark stream. Hydrobiologia, 437, 165-170. 